\title{
MEMBANGUN KONSEP IDEAL PENERAPAN ASAS IKTIKAD BAIK DALAM HUKUM PERJANJIAN
}

\author{
Miftah Arifin \\ Fakultas Ekonomi, Universitas Islam Nahdlatul Ulama, Jepara \\ miftah012001@gmail.com
}

\begin{abstract}
Abstrak
Penelitian ini bertujuan untuk mengakaji dan menganalisa konsep ideal dalam penerapan iktikad baik dalam hukum perjanjian. Pengaturan iktikad baik sebaiknya dirumuskan sebagai "sikap atau perilaku berpegang teguh pada perjanjian untuk memberikan kepada lawan janji apa yang menjadi haknya dan tidak mencari-cari celah untuk melepaskan diri dari apa yang telah diperjanjikan berdasarkan kepatutan dan kerasionalan. Standar yang digunakan dalam iktikad baik objektif adalah standar yang objektif yang mengacu kepada suatu norma yang objektif. Penelitian ini menggunakan metode yuridis normatif. Perilaku para pihak dalam perjanjian harus diuji atas dasar norma-norma objektif yang tidak tertulis yang berkembang di dalam masyarakat. Norma tersebut dikatakan objektif karena tingkah laku didasarkan pada anggapan para pihak sendiri, tetapi tingkah laku tersebut harus sesuai dengan anggapan umum tentang iktikad baik tersebut. Fungsi iktikad baik yang ketiga adalah fungsi membatasi dan meniadakan. Beberapa para pakar hukum sebelum perang berpendapat bahwa iktikad baik juga memiliki fungsi ini. Mereka mengajarkan bahwa suatu perjanjian tertentu atau suatu ketentuan undang-undang mengenai kontrak itu dapat dikesampingkan, jika sejak dibuatnya kontrak itu keadaan telah berubah, sehingga pelaksanaan kontrak itu menimbulkan ketidakadilan.
\end{abstract}

Kata kunci : asas hukum; iktikad baik; hukum perjanjian 
p-ISSN : 2541-2345, e-ISSN : 2580-8842

\title{
ESTABLISH THE IDEAL CONCEPT IN APPLICATION THE PRINCIPLE OF GOOD FAITH IN CONTRACT LAW
}

\author{
Miftah Arifin \\ Faculty of Economics, Islamic University of Nahdlatul Ulama, Jepara \\ miftah012001@gmail.com
}

\begin{abstract}
This study aims to review and analyze the ideal concepts in the application of good faith in contract law. Good faith arrangements should be formulated as "attitudes or behaviors adhering to the agreement to give the opponent the promise of what is his right and not looking for loopholes to break away from what has been promised based on propriety and rationality. Standards used in objective good faith are objective standards that refer to an objective norm. This research uses the normative juridical method. The behavior of the parties to the agreement must be tested on the basis of unwritten objective norms that develop in society. The norm is said to be objective because behavior is based on the assumptions of the parties themselves, but the behavior must be in accordance with the general assumptions about good faith. The third function of good faith is the function of limiting and eliminating. Some prewar legal experts argue that good faith also has this function. They teach that a certain agreement or a statutory provision regarding the contract can be set aside, if since the contract was made the situation has changed, so that the implementation of the contract raises injustice.
\end{abstract}

Keywords: legal principle; good faith; legal agreement

\section{PENDAHULUAN}

\section{A. Latar Belakang}

Perjanjian menurut ketentuan Pasal 1313 KUHPerdata adalah suatu perbuatan dimana satu orang atau lebih mengikatkan diri terhadap satu orang lain atau lebih. Hal ini berarti bahwa perjanjian menimbulkan adanya hak-hak dan kewajiban-kewajiban diantara para pihak yang membuatnya. ${ }^{1}$ Di dalam setiap perjanjian dengan maksud bahwa setiap perjanjian yang telah dibuat dan disepakati bersama oleh para pihak harus dilaksanakan dengan iktikad baik, sebagaimana yang ditentukan dalam Pasal 1338 ayat (3) KUHPerdata yang menyebutkan bahwa semua perjanjian harus dilakukan dengan iktikad baik. Iktikad baik diwaktu membuat suatu perjanjian berarti kejujuran. Orang yang beriktikad baik menaruh kepercayaan sepenuhnya kepada

\footnotetext{
${ }^{1}$ Subekti, Aspek-Aspek Hukum Perikatan Nasional, PT. Citra Aditya Bakti, 1992, Bandung
} hlm. 17 . 
pihak lawan yang dianggapnya jujur dan tidak menyembunyikan sesuatu yang buruk yang dikemudian hari dapat menimbulkan kesulitan-kesulitan. ${ }^{2}$

Asas iktikad baik itu mempunyai dua pengertian yaitu :

1. Iktikad baik dalam arti obyektif, bahwa suatu perjanjian yang dibuat haruslah dilaksanakan dengan mengindahkan norma-norma kepatutan dan kesusilaan yang berarti bahwa perjanjian itu harus dilaksanakan sedemikian rupa sehingga tidak merugikan salah satu pihak.

2. Iktikad baik dalam arti subyektif, yaitu pengertian iktikad baik yang terletak dalam sikap batin seseorang. Didalam hukum benda, iktikad baik ini bisa diartikan dengan kejujuran.

Iktikad baik dalam arti subyektif bisa diartikan kejujuran seseorang dalam melakukan suatu perbuatan hukum yaitu apa yang terletak pada sikap batin seseorang pada waktu diadakan perbuatan hukum. Iktikad baik dalam arti subyektif ini diatur dalam Pasal 531 Buku II KUHPerdata. Tak hanya itu saja, di dalam beberapa peraturan perundang-undangan juga mencantumkan tentang kejujuran, antara lain UndangUndang Nomor 8 Tahub 1999 tentang Perlindungan Konsumen, Undang-Undang Nomor 8 Tahun 1995 tentang Pasar Modal.

Iktikad baik dalam suatu perjanjian terdapat dalam Pasal 1338 ayat (3) KUHPerdata, selanjutnya yang menyatakan bahwa persetujuan-persetujuan harus dilaksanakan dengan iktikad baik. Akan tetapi dalam pasal tersebut tidak disebutkan secara ekplisit apa yang dimaksud dengan "iktikad baik". Akibatnya orang akan menemui kesulitan dalam menafsirkan dari iktikad baik itu sendiri. Karena iktikad baik merupakan suatu pengertian yang abstrak yang berhubungan dengan apa yang ada dalam alam pikiran manusia. ${ }^{3}$

Kemudian menurut Munir Fuady, rumusan dari Pasal 1338 ayat (3) KUHPerdata tersebut mengidentifikasikan bahwa sebenarnya iktikad baik bukan merupakan syarat sahnya suatu perjanjian sebagaimana syarat yang terdapat dalam Pasal 1320 KUH Perdata. Unsur iktikad baik hanya diisyaratkan dalam hal "pelaksanaan" dari suatu perjanjian, bukan pada "pembuatan" suatu perjanjian. Sebab unsur "iktikad baik" dalam hal pembuatan suatu perjanjian sudah dapat dicakup oleh unsur "kausa yang legal" dari Pasal 1320 tersebut. ${ }^{4}$

Konsekuensinya, hokum membiarkan manusia atau individual untuk bebas menentukan apa yang hendak disepakati. Manusia tidak hanya bebas untuk melakukan

\footnotetext{
${ }^{2}$ Subekti, Hukum Perjanjian, PT Citra Aditya Bakti, 1983, Bandung, hlm 25

${ }^{3}$ Gary Hadi, Penerapan Asas Iktikad Baik Dalam Perjanjian Sewa-Menyewa (Studi Terhadap Perjanjian Sewa Menyewa Oulet Di Hermes Building Medan ), USU Law Journal Vol.5.No.2, Fakultas Hukum Universitas Sumatera Utara, 2017, Medan.

${ }^{4}$ Munir Fuady, Hukum Kontrak (Dari Sudut Pandang Hukum Bisnis), PT. Citra Aditya Bakti, 2001, Bandung, hlm 81.
} 
atau tidak melakukan suatu perbuatan yang dirumuskan oleh undangundang, melainkan dalam arti lebih luas, karena dengan kebebasan itulah ia dapat menentukan pengaturan yang paling baik bagi dirinya. ${ }^{5}$

Kebebasan berkontrak merupakan "ruh" atau "nafas" dari sebuah perjanjian, yang dilandaskan pada kesadaran bahwa hanya para pihaklah yang mengetahui kebutuhannya untuk melakukan hubungan kontraktual atau perjanjian. Suatu kontrak perdagangan (bisnis) selalu ada kemungkinan timbulnya konflik atau sengketa yang disebabkan adanya conflict of interest maupun kelalaian salah satu pihak dalam memenuhi isi perjanjian. Makin banyak dan luasnya kegiatan perdagangan, frekuensi terjadinya sengketa makin tinggi. Hal ini berarti makin banyak sengketa yang harus diselesaikan. Merupakan hal yang wajar apabila dalam hubungan perdagangan pada suatu saat mengalami pertikaian atau konflik (conflict), hal ini pada hakekatnya merupakan salah satu bentuk dari interaksi sosial dalam kehidupan bermasyarakat. Konflik akan berkembang menjadi sengketa apabila pihak yang merasa dirugikan menyatakan rasa tidak puas pada pihak yang menimbulkan kerugian pada pihak lain. ${ }^{6}$

Perjanjian merupakan sebuah kesepakatan yang dibuat oleh para pihak yang membuat perjanjian. Para pihak sepakat untuk mengikatkan diri satu dengan lainnya baik untuk memberikan sesuatu, berbuat sesuatu, atau tidak berbuat sesuatu. Kesepakatan ini akan melahirkan hak dan kewajiban diantara para pihak. ${ }^{7}$ Kontrak sebagaimana diatur dalam Pasal 1313 KUHPerdata, bahwa perjanjian atau persetujuan adalah suatu perbuatan hukum dimana seseorang atau lebih mengikatkan dirinya terhadap seseorang atau lebih. Atau juga dapat diartikan suatu peristiwa dimana seseorang berjanji kepada seseorang lain, atau dimana 2 (dua) orang saling berjanji untuk melaksanakan sesuatu. Hakikat hukum kontrak pada dasarnya untuk memenuhi kebutuhan hukum pelaku bisnis.

Gagasan utama kebebasan berkontrak berkaitan dengan penekanan akan persetujuan dan maksud atau kehendak para pihak. Selain itu, gagasan kebebasan berkontrak juga berkaitan dengan pandangan bahwa kontrak adalah hasil dari pilihan bebas (free choice). Dengan gagasan utama ini, kemudian dianut paham bahwa tidak seorang pun terikat kepada kontrak sepanjang tidak dilakukan atas dasar adanya pilihan bebas untuk melakukan sesuatu. ${ }^{8}$

${ }^{5}$ Agus Yudha Hernoko, Hukum Perjanjian: Asas Proporsionalitas dalam Kontrak Komersial, LaksBang Mediatama, 2008, Yogyakarta, hlm. 2.

${ }^{6}$ Dewi Tuti Muryati, Pengaturan Dan Mekanisme Penyelesaian Sengketa Nonlitigasi Di Bidang Perdagangan, Journal Dinamika Sosbud Vol. 13 Nomor 1 Juni 2011, Lembaga Penelitian dan Pengabdian Masyarakat Universitas Semarang, 2011, Semarang, hlm. 50.

${ }^{7}$ Ridwan Khairandy, Hukum Kontrak Indonesia, UII Press, 2013, Yogyakarta, hlm. 40

${ }^{8}$ Ridwan Khairandy, Landasan Filosofis Kekuatan Mengikatnya Kontrak, Jurnal Hukum Ius Quia Iustum No. Edisi Khusus Vol. 18 Oktober 2011, Fakultas Hukum Universitas Islam Indonesia, 2011, Yogyakarta, hlm 42. 
Gagasan tersebut menjadi prinsip utama baik dalam sistem civil law maupun common law bahwa kontrak perdata individual di mana para pihak bebas menentukan kesepakatan kontraktual tersebut. Bagi mereka yang memiliki kemampuan bertindak untuk membuat kontrak (capacity) memiliki kebebasan untuk mengikatkan diri, menentukan isi, akibat hukum yang timbul dari kontrak itu. ${ }^{9}$

Subekti menjelaskan bahwa iktikad baiak menurut Pasal 1338 ayat (3) KUHPerdata merupakan satu dari beberapa sendi yang terpenting dari hukum kontrak yang memberikan kekuasaan kepada hakim untuk mengawasi pelaksanaan suatu kontrak agar tidak melanggar kepatutan dan keadilan. Ini berarti bahwa hakim berwenang untuk menyimpang dari kontrak jika pelaksanaan kontrak yang melanggar perasaan keadilan (recht gevoel) satu diantar dua pihak. Asas iktikad baik menuntut adanya kepatutan dan keadilan, dalam arti tuntutan adanya kepastian hukum yang berupa pelaksanaan kontrak tidak boleh melanggar norma-norma kepatutan dan nialinilai kedilan. ${ }^{10}$

Istilah perjanjian sudah lazim didengan dan dipergunakan dalam lapangan bisnis, dalam segala tingkatan. Perjanjian merupakan keputusan kehendak dua pihak, sehingga orang terikat pada perjanjian karena kehendaknya sendiri, ${ }^{11}$. Menurut Subekti, "perjanjian merupakan sumber perikatan, sedangkan perikatan diartikan sebagai suatu perhubungan hukum antara dua orang atau dua pihak, berdasarkan mana pihak yang satu berhak menuntut sesuatu hal dari pihak yang lain, dan pihak yang lain berkewajiban untuk memenuhi tuntutan itu ${ }^{12}$. Lebih lanjut dikatakan Subekti, bahwa: "suatu perjanjian adalah suatu peristiwa dimana seseorang berjanji kepada seorang lain atau dimana dua orang itu saling berjanji untuk melaksanakan sesuatu hal.

Berdasarkan peristiwa ini, timbulah suatu hubungan hukum antara dua orang tersebut yang dinamakan perikatan ${ }^{13}$. Oleh karena itu, tidak dilaksanakannya atau tidak dipenuhinya prestasi oleh salah satu pihak akan melahirkan tuntutan pihak yang lain untuk memenuhi prestasi tersebut. Hubungan hukum antara pihak-pihak yang mengadakan perjanjian tersebut sifatnya hubungan hukum perseorangan (persoonlijke), dan bukan hubungan hukum yang bersifat kebendaan (zaakelijke). Menurut ketentuan Pasal 1233 KUHPdt, sumber perikatan adalah undang-undang atau persetujuan, selengkapnya ketentuan pasal ini dirumuskan: "Tiap-tiap perikatan dilahirkan baik karena persetujuan, baik karena undangundang. Persetujuan yang berisikan janji-janji yang termuat di dalamnya dianggap sebagai janji antara para pihak yang membuatnya”.

9 K.M. Sharma, "From Sanctity to Fairness: An Uneasy Transition in The Law of Contract?”, New York Law School Journal of International Law \& Comparative Law, Vol. 18, 1999, New York, hlm.18.

${ }^{10}$ Muhammad Syaifuddin, Hukum Kontrak, Mandar Maju, 2012, Bandung, hlm. 94.

${ }^{11}$ L.J. van Apeldoorn, Pengantar Ilmu Hukum, Pradnya Paramita,1980, Jakarta, hlm., 183.

${ }^{12}$ Marthainis Badul Hay, Hukum Perdata Material (jilid II), Pradnya Paramita, 1984, Bandung, hlm. 91 hlm. 83

${ }^{13}$ Richard Eddy, Aspek Legal Properti: Teori, Contoh dan Aplikasi, CV. Andi Offset, 2010, Yogyakarta, 
Pelaksanaan asas iktikad baik bukan hal sederhana, hal ini penting dilaksanakan dalam setiap kontrak yang telah disepakati bersama. Atas dasar latar belakang tersebut penyusun tertarik untuk meneliti lebih jauh asas iktikad baik dalam plaksanaan perjanjian maka penulis mengambil tema "Membangun Konsep Ideal Penerapan Asas Iktikad Baik Dalam Hukum Perjanjian".

B. Rumusan Masalah

Berdasarkan latar belakang diatas, agar lebih terfokusnya pembahasan, maka rumusan masalah dibatasi menjadi :

1. Bagaimanakah karakteristik asas iktikad baik dalam membangun konsep ideal penerapan asas iktikad baik dalam hukum perjanjian?

2. Bagaiamana penerapan asas iktikad baik dalam membangun konsep ideal penerapan asas iktikad baik dalam hukum perjanjian?

\section{Metode Penelitian}

Penelitian merupakan terjemahan dari bahasa Inggris yaitu research yang berasal dari kata re (kembali) dan to search (mencari). Sehingga jika dua kata tersebut digabungkan maka mempunyai arti mencari kembali. Pencarian kembali ini ditujukan kepada pengetahuan yang benar. Sejalan dengan pengertian tersebut di atas, Sutrisno Hadi mendefinisikan kata "research" sebagai usaha untuk menemukan, mengembangkan dan menguji kebenaran suatu pengetahuan. Usaha-usaha tersebut dilakukan dengan menggunakan metode-metode ilmiah. ${ }^{14}$

Sementara itu Soeryono Soekanto menjelaskan arti penelitian adalah suatu kegiatan ilmiah yang berkaitan dengan analisa dan konstruksi yang dilakukan secara metodologis, sistematis dan konsisten. Beberapa pengertian tersebut dapat disimpulkan bahwa untuk tercapainya suatu hasil yang baik dari sebuah penelitian dibutuhkan suatu metode.

Penelitian hukum merupakan suatu kegiatan ilmiah yang didasarkan pada metode, sistematika dan pemikiran tertentu yang bertujuan untuk mempelajari satu atau beberapa gejala hukum tertentu dengan jalan menganalisanya. Kecuali itu maka juga diadakan pemeriksaan yang mendalam terhadap fakta hukum tersebut untuk kemudian mengusahakan suatu pemecahan atas permasalahan-permasalahan yang timbul di dalam gejala yang bersangkutan ${ }^{15}$

Agar penelitian ini mampu mencapai tujuan dengan tetap mengacu pada standar ilmiah sebuah karya penelitian, maka penyusun menggunakan berbagai metode yang ada sebagai acuan dalam melakasanakan penelitian. Adapun diantara metode-metode yang digunakan oleh penyusun, sebagai berikut :

\section{Jenis Penelitian}

Penelitian ini bersifat yuridis normatif dimana penulis menelaah asas- asas serta doktrin yang berkaitan dengan pokok permasalahan secara mendalam. Penelitian yuridis normatif dalam penelitian hukum ini dilakukan dengan menelusuri, mengkaji, meneliti data sekunder (kepustakaan) yang berkaitan dengan materi penelitian. Pendekatan yuridis normatif merupakan pendekatan utama karena titik tolak

\footnotetext{
${ }^{14}$ Sutrisno Hadi, Metodologi Research, Jilid I, Yayasan Penerbit Fakultas Psikologi Universitas Gadjahmada, 1969, Yogyakarta, hlm. 4

${ }^{15}$ Soerjono Soekamto, Pengantar Penelitian Hukum, UI-Press, 2006, Jakarta, hlm. 43.
} 
penelitian ini adalah mengungkapkan kaedah-kaedah normatif baik dari sumber yang didokumentasikan maupun informasi dari pihak bank dalam perjanjian kredit. Asasasas yang terkait dalam teori ini adalah asas iktikad baik dan asas kebebasan berkontrak. Sedangkan doktrin yang dipakai adalah pendapat dari Treitel meliputi kebebasan para pihak untuk menentukan sendiri isi perjanjian yang ingin mereka buat. Asas umum yang kedua adalah pada umumnya seseorang menurut hukum tidak dapat dipaksa untuk memasuki suatu perjanjian.

\section{Jenis Data}

Jenis data yang digunakan dalam penilitian ini adalah data sekunder. Data sekunder terdiri dari bahan-bahan hukum yang meliputi bahan hukum primer dan bahan hukum sekunder. Di dalam penelitian, sumber data terbagi menjadi 2 (dua) yaitu sumber data yang diperoleh secara langsung dari masyarakat yang selanjutnya disebut sebagai data primer dan data yang diperoleh dari bahan-bahan pustaka yang kemudian disebut sebagai data sekunder. Penelitian hukum dengan cara meneliti bahan pustaka atau data sekunder dinamakan penelitian hukum normatif atau penelitian hukum kepustakaan. Bahan kepustakaan dapat dikelompokkan menjadi 3 (tiga) yaitu: Bahan hukum primer. Bahan hukum primer yaitu bahan hukum yang mengikat.

Bahan hukum sekunder. Bahan hukum sekunder yaitu bahan hukum yang memberi petunjuk dan menjelaskan bahan hukum primer antara lain: Buku-buku mengenai perjanjian; Karya-karya ilmiah di bidang hukum; Bahan-bahan kepustakaan yang berasal dari majalah, artikel, jurnal, tesis, surat kabar dan website; Laporanlaporan penelitian yang relevan dengan bidang kajian. Bahan hukum tersier yaitu bahan hukum yang melengkapi bahan hukum primer dan sekunder antara lain: Kamus Besar Bahasa Indonesia; Kamus Hukum.

\section{Cara Pengumpulan Data}

Penelitian ini termasuk dalam penelitian kepustakaan, yaitu suatu penelitian yang bertujuan mendapatkan data sekunder dengan cara melakukan penelaahan terhadap peraturan perundang-undangan, literatur, karya-karya hukum dan bahanbahan tertulis lainnya yang berkaitan dengan penelitian.

\section{Alat Pengumpulan Data}

Dalam penelitian hukum normatif alat pengumpulan data dilakukan dengan melakukan studi pustaka terhadap bahan-bahan hukum primer, sekunder dan tersier. Alat pengumpulan data untuk memperoleh data yang dibutuhkan dilakukan dengan cara melakukan studi dokumen untuk mendapatkan gambaran secara umum mengenai hal-hal yang berhubungan dengan permasalahan yang diteliti.

\section{Analisis Data}

Data yang diperoleh dari penelitian kepustakaan selanjutnya dianalisis secara kualitatif. Data yang terkumpul kemudian dikelompokkan dan dipilah- pilah dicari yang relevan dan representatif yang berhubungan dengan permasalahan, diteliti dan dipelajari secara mendalam, ditelaah dan dipaparkan secara deskriptif kemudian dibuat kesimpulan dan diharapkan dapat menjawab permasalahan yang dibahas.

\section{PEMBAHASAN}

\section{Karakteristik Asas Iktikad Baik Dalam Membangun Konsep Ideal Penerapan Asas Iktikad Baik Dalam Hukum Perjanjian}

Kajian tentang iktikad baik dapat ditemukan di dalam berbagai literatur hukum. Walaupun demikian sampai sekarang belum ada undang-undang mapun 
doktrin yang memberikan batasan yang jelas menyangkut pengertian iktikad baik sebagai norma/aturan hukum dan hubungannya dengan iktikad baik sebagai asas hukum. Dari hasil penelitian ditemukan bahwa terdapat kecenderungan kajian mencampur adukan pengertian iktikad baik sebagai aturan hukum dan iktikad baik sebagai asas hukum. ${ }^{16}$ Sebagai contoh pembahasan iktikad baik yang terdapat dalam Pasal 1338 ayat (3) BW diartikan sebagai asas hukum kontrak sehingga melahirkan kesimpulan iktikad baik hanya ada dalam pelaksanaan kontrak. Dengan perkataan lain, sampai sekarang belum tegas pembedaan makna dan fungsi iktikad baik sebagai aturan hukum dan iktikad baik sebagai asas hukum kontrak. Pemahaman iktikad baik sebagai aturan hukum dan iktikad baik sebagai asas hukum kontrak sangat penting untuk menjawab perbedaan pendapat terkait dengan kewajiban iktikad baik pada tahapan prakontrak.

Hubungan antara aturan dan asas sifatnya problematis, Ada pendapat melakukan pembedaan secara gradual, misalnya pembedaan antara keduanya dicari dalam karakter asas-asas hukum yang cenderung lebih abstrak ketimbang aturan. Dworkin ${ }^{17}$ mengajukan dua kriteria pembeda yaitu, pertama yang terpenting ialah derajat konretisasi dan kedua adalah berkenaan dengan persoalan apakah dengan aturan-aturan yang ada berlaku atau tidak berlaku; aturan-aturan yang ada tersebut niscaya memiliki karakter berlaku atau tidak, sedemikian sehingga tidak ada tempat untuk menimbang-nimbang jalan tengah. ${ }^{18}$

Aturan-aturan hukum yang ada tidak dapat menetapkan apa hukumnya atau memecahkan persoalan akan dibutuhkan bantuan asas-asas hukum untuk memberikan makna terhadap aturan-aturan hukum yang telah ada. Setiap kasus (hukum) harus dipecahkan dan ini berarti pula setiap kali kita akan memerlukan penafsiran sebagai semacam pelengkap.

Menurut Leijte, Asas hukum haruslah "diperjuangkan bukan pada tataran penilaian rasio manusia, melainkan pada tataran kesusilaan. Asas hukum tidak sekadar kontrak hendaknya dapat dibedakan atas; iktikad baik sebagai aturan hukum kontrak dan iktikad baik sebagai asas hukum kontrak. Sebagai aturan hukum konkret termasuk dalam tataran dogmatik hukum, sedangkan sebagai asas hukum termasuk dalam tataran filsafat hukum. Dengan demikian iktikad baik sebagai aturan hukum konkret

\footnotetext{
${ }^{16}$ Ridwan Khairandy, Iktikad Baik dalam Pelaksanaan Kontrak: Super Eminent Principle yang Memerlukan Pengertian dan Tolok Ukur Objektif, Jurnal Hukum “Ius Quia Iustum” No. 3 Vol. 14 Juli 2008, Fakultas Hukum Universitas Islam Indonesia, 2008, Yogyakarta, hlm 351.

17 R.Dworkin (Book 1), Taking Richts Seriously, Harvard University Press, Cambrigde, Massachcussetts, 1977 , p. 24.

${ }^{18}$ R.Dworkin (Book 2), Low”s Empire, Fontana Press, Herper Collins Publishers, London, 1991, p. 50 .
} 
jika ditafsirkan secara gramatikal ${ }^{19}$ mengandung makna hanya ada pada tahap pelaksanaan kontrak. Berbeda dengan iktikad baik dimaknai sebagai asas hukum kontrak yang wilayah penerapannya tidak terbatas pada pelaksanaan kontrak tetapi pada semua tahapan kontrak, yaitu tahapan prakontrak, pelaksanaan kontrak dan penyelesaian sengketa. ${ }^{20}$

Iktikad baik sebagai asas hukum kontrak hakikatnya adalah kejujuran dan kepatutan/keadilan yang mengandung makna kepercayaan, transparansi, otonom, taat norma, tanpa paksaan dan tanpa tipu daya. Kejujuran dikonktretkan ke dalam aturan hukum positif antara lain adalah; Pasal 530, 531, 533 dan 548 BW tentang beziter yang beriktikad baik, Pasal 1963; 1966 dan 1977 BW tentang kepemilikan terkait dengan kadaluawarsa; Pasal 1320 BW khususnya persyaratan kata sepakat dan suatu causa yang halal. Kepatutan/keadilan dikonkritkan dikonkritkan ke dalam aturan hukum Pasal 1321, 1323, 1328 BW tentang kehilafan, paksaan dan penipuan dalam pembuatan kontrak; Pasal 1348 BW tentang pembayaran dengan beriktikad.

Pembatalan suatu kontrak adalah satu bagian yang paling penting untuk dituntut oleh kreditur (penggugat) dalam gugatannya, selain dari tuntutan pengambilan biaya, ganti rugi dan bunga. Pembatalan suatu kontrak dalam hal ini harus terlebih dahulu ditegaskan pengertiannya. Apakah pembatalan tersebut dimaksudkan terhadap seluruh keberadaan dari kontrak tersebut sehingga seakan-akan kontrak tersebut tidak pernah ada dari awal, ataukah penghentian (pembatalan) seluruh konsekuensi hukum dari pelaksanaan kontrak tersebut kedepannya sebagai akibat dari telah terjadinya tindakan wan prestasi. Pemahaman ini akan sangat berhubungan dengan tuntutan penggantian biaya yang akan diajukan sebagai akibat dari pembatalan kontrak tersebut. $^{21}$

Iktikad baik tersebut tidak hanya mengacu kepada iktikad baik para pihak, tetapi harus pula mengacu kepada nilai-nilai yang berkembang dalam masyarakat, sebab iktikad baik merupakan bagian dari masyarakat. Iktikad baik ini akhirnya mencerminkan standar keadilan dan kepatutan masyarakat. Makna yang demikian itu menjadikan iktikad baik sebagai suatu universal social force yang mengatur hubungan antar sosial mereka, yakni setiap warganegara harus memiliki kewajiban untuk bertindak dengan iktikad baik terhadap semua warganegara.

${ }^{19}$ Harisa, Novran Harisa, 2018, Asas Itikat Baik dalam Perjanjian Arbitrasi sebagai Metode Penyelesaian Sengketa, Jurnal Aktualita, Vol.1 No.1 (Juni) 2018, Universitas Islam Bandung, 2018, Bandung, hlm 266. DOI: https://doi.org/10.29313/aktualita.v1i1.3722

${ }^{20}$ Henry P. Panggabean, Penyalahgunaan Keadaan, (Misbruik van Omstandigheden) sebagai Alasan (Baru) untuk Pembatalan Perjanjian (Berbagai Perkembangan Hukum di Belanda), Liberty, 1999, Yogyakarta, hal. 7.

${ }^{21}$ Ricardo Simanjuntak, Teknik Perancangan Kontrak Bisnis, Kontan Publishing, 2011, Jakarta, hlm. 231 
Sesuai dengan hukum Kanonik, kewajiban iktikad baik menjadi suatu norma moral yang universal yang secara individual ditentukan oleh kejujuran dan kewajiban seseorang kepada Tuhan. Setiap individu harus memegang teguh atau harus mematuhi janjianya. Para sarjana hukum Kanonik mengkaitkan iktikad baik dengan good conscience. ${ }^{22}$ Mereka memasukkan makna religious faith ke dalam good faith dalam pengertian hukum. Dengan konsep iktikad dalam hukum Kanonik ini menggunakan standar moral subjektif yang didasarkan pada kejujuran individual. Konsep ini jelas berlainan dengan konsep iktikad baik dalam hukum Yunani dan Romawi yang memandang iktikad baik sebagai suatu universal social force.

Iktikad baik di dalam fase pra kontrak disebut juga sebagai iktikad baik subjektif. Kemudian iktikad baik dalam fase pelaksanaan kontrak disebut iktikad baik ojektif. $^{23}$

1. Iktikad baik dalam arti objektif, bahwa suatu perjanjian yang dibuat haruslah dilaksanakan dengan mengindahkan norma-norma kepatutan dan kesusilaan yang berarti bahwa perjanjian itu harus dilaksanakan sedemikian rupa sehingga tidak merugikan salah satu pihak.

2. Iktikad baik dalam arti subjektif, yaitu pengertian iktikad baik yang terletak dalam sikap batin seseorang. Di dalam hukum benda iktikad baik ini biasa diartikan dengan kejujuran.

Standar atau tolak ukur iktikad baik pelaksanaan kontrak adalah standar objektif. Dalam konsep hukum kontrak yang berkaitan dengan pengertian bertindak menurut konsep iktikad baik mengacu kepada ketaatan akan reasonable commercial standard of fair dealing, yang menurut legislator Belanda disebut bertindak sesuai dengan redelijkheid en billijkheid (reasonableness and equity). ${ }^{24}$

Iktikad baik telah menjadi asas yang sangat penting dalam hukum. Asas ini telah diterima dalam berbagai sistem hukum. Asas ini memiliki fungsi yang sangat penting dalam hukum kontrak. Di dalam doktrin dan yurisprudensi di Belanda, asas iktikad dalam perkembangannya memiliki beberapa fungsi sebagaimana dijelaskan.

Fungsi iktikad baik yang ketiga adalah fungsi membatasi dan meniadakan. Beberapa para pakar hukum sebelum perang berpendapat bahwa iktikad baik juga memiliki fungsi ini. Mereka mengajarkan bahwa suatu perjanjian tertentu atau suatu ketentuan undang-undang mengenai kontrak itu dapat dikesampingkan, jika sejak

${ }^{22}$ Zahry Vandawati Chumaidah, Menciptakan Iktikad Baik Yang Berkeadilan Dalam Kontrak Asuransi Jiwa, Jurnal Yuridika : Volume 29 No 2, Mei-Agustus 2014, Universitas Airlangga, Surabaya, hlm. 245. DOI: $10.20473 /$ ydk.v29i2.370

${ }^{23}$ Antari Innaka, Penerapan Asas Iktikad Baik Tahap Prakontraktual Pada Perjanjian Jual Beli Perumahan, Mimbar Hukum Volume 24, Nomor 3, Oktober 2012, Universitas Gadjahmada, Yogyakarta, hlm. 421. DOI: https://doi.org/10.22146/jmh.16122

${ }^{24}$ Ery Agus Priyono, Peranan Asas Iktikad Baik Dalam Kontrak Baku (Upaya Menjaga Keseimbangan Bagi Para Pihak), Diponegoro Private Law Review Vol. 1 No. 1 November 2017, Fakultas Hukum Universitas Diponegoro,Semarang, hlm. 19. 
dibuatnya kontrak itu keadaan telah berubah, sehingga pelaksanaan kontrak itu menimbulkan ketidakadilan. Dalam keadaan yang demikian itu, kewajiban kontraktual dapat dibatasi, bahkan ditiadakan seluruhnya atas dasar iktikad baik.

Prinsip iktikad baik, yang dipredikis secara lambat laun akan menggeser penggunaan prinsip kebebasan berkontrak dalam sebuah perjanjian, bukan lagi sekedar wacana, akan tetapi sudah menjadi kebutuhan praktek, dan pada saat ini telah diikuti oleh sebagaian negara-negara yang menganut civil law system maupun yang common law system. Hal ini dapat dibuktikan dengan diaturnya prinsip iktikad baik, meskipun belum cukup memadahi, di dalam peraturan perundang-undangan negara yang menganut civil law system maupun yang common law system tersebut, meskipun tidak semua negara mengadopsi konsep iktikad baik.

\section{Bagaiamana Penerapan Asas Iktikad Baik Dalam Membangun Konsep Ideal Penerapan Asas Iktikad Baik Dalam Hukum Perjanjian.}

Telah diuraikan mengenai asas kepatutan dan keadilan sebagai salah satu asas yang dapat digunakan sebagai tolok ukur iktikad baik dalam perjanjian. Namun demikian kepatutan dan keadilan tersebut pada akhirnya juga masih memerlukan penafsiran lebih jauh dalam praktek oleh hakim-hakim yang berwenang mengambil keputusan, sebab kepatutan sangat relatif penilaianya sangat tergantung pada perspektif masyarakat, dan keadilan pun juga demikian, dari teorinya Aristoteles, Plato sampai dengan teori keadilan modern dari John Rawls, dan Bentham juga belum mampu memberikan kejelasan yang memuaskan terhadap konsep adil dan keadilan tersebut.

Iktikad baik berkaitan erat dengan tata kehidupan bermasyarakat karena akan menyangkut terhadap kesadaran hukum masyarakat yang memerlukan pembinaan dan pengaturan. ${ }^{25}$ Pelaksanaan lalu lintas hukum diharapkan sekali agar masyarakat selalu bertindak dengan dilandasi iktikad baik, sehingga dapat menunjang usaha mewujudkan masyarakat adil dan makmur.

${ }^{25}$ Djaja S. Meliala, Masalah Iktikad Baik dalam KUHPerdata, Binacipta, 1987, Bandung, hlm. 
Sistem hukum (Tatang Amirin,1986:4) ${ }^{26}$ perjanjian dibangun berdasarkan asas-asas hukum (Henry Campbell Black, 1991:828). ${ }^{27}$ Asas hukum berfungsi sebagai pondasi yang memberikan arah, tujuan serta penilaian fundamental, mengandung nilai-nilai dan tuntutan-tuntutan etis. Mariam Darus mengemukakan bahwa sistem hukum merupakan kumpulan asas- asas hukum yang terpadu di atas mana dibangun

${ }^{26}$ Teori sistem merupakan aliran yang paling penting dalam positivisme hukum, yang intinya bahwa hukum adalah suatu stelsel dari aturan yang berkaitan satu sama lain secara organis, secara piramida dari norma-norma yang terbentuk secara hierarki. Lihat N.E. Algra dan K.Van Duyvendijk, Mula Hukum, Jakarta: Binacipta, 1983, hlm. 139. Mengenai pengertian sistem, William A Schrode dan Voich menjelaskan bahwa: the term "system" has two important connotations. The first is the notion of system as an entity or thing which has particular order or structural arrangement of its parts. The second is the notion of system as a plan, methode, device, or procedure for accomplishing something . Lihat Tatang Amirin, Pokok-Pokok Teori Sistem, Jakarta: Rajawali, 1986, hlm. 4.

${ }^{27}$ Menurut Henry Campbell Black, "principle is the fundamental of truth or doctrine, as of law, a comprehensive law or doctrine which furnishes a basic or origin for others", Henry Campbell Black, Black's Law Dictionary, 1991, St. Paul Minn, West Group, hlm. 828 
tertib hukum (Mariam Darus Badruzzaman, 1990:5). ${ }^{28}$ Pandangan ini menunjukkan arti sistem hukum dari segi substantif. Dilihat dari segi substantif, asas hukum perjanjian adalah suatu pikiran mendasar tentang kebenaran untuk menopang norma hukum dan menjadi elemen yuridis dari suatu sistem hukum perjanjian. Dalam suatu sistem yang baik, tidak boleh terjadi suatu pertentangan atau perbenturan antara bagian-bagian tersebut dan juga tidak boleh terjadi suatu duplikasi atau tumpang tindih.

Salah satu penyebab perjanjian itu dapat dibatalkan manakala perjanjian itu ada unsur penyalahgunaan keadaan, dimana penyalah gunaan keadaan merupakan salah satu indikasi tidak adanya iktikad baik dalam sebuah kontrak. ${ }^{29}$ Penyalagunaan keadaan dalam sistem common law merupakan doktrin yang menentukan pembatalan perjanjian yang dibuat berdasarkan tekanan yang tidak patut, tetapi tidak termasuk dalam kategori paksaan (duress). Penyalahgunaan keadaan merupakan perbuatan yang dilatarbelakangi oleh keadaan tidak seimbang antara para pihak dalam sebuah perjanjian, dan dalam kondisi yang demikian pihak yang kuat memanfaatkan kedudukan pihak yang lemah. Pihak yang lemah tidak memiliki kesempatan untuk mendiskusikan segala sesuatu yang menjadi hak dan kewajibanya dalam sebuah perjanjian. Penyalahgunaan keadaan terjadi manakala seseorang di dalam suatu perjanjian dipengaruhi oleh suatu hal yang menghalanginya untuk melakukan penilaian (judgment) yang bebas dari pihak lainya, sehingga tidak dapat mengambil keputusan yang independen.

Produk legislatif terbaru yang berkaitan dengan iktikad baik terdapat dalam Pasal 6.248.1 BW (Baru) Belanda. Menurut Hartkamp, pembentuk Undang-Undang telah membedakan iktikad baik dalam makna ketaatan akan reasonable commercial standard of fair dealing dari iktikad baik dalam makna honesty in fact. Untuk mencegah kemungkinan timbulnya kebingungan, pembentuk Undang-Undang Belanda menggunakan istilah iktikad baik dalam makna yang pertama saja dimana iktikad baik kemudian dikarakteristikkan sebagai reasonableness (redelijkheid) dan equity (billijkheid)

Pengaturan tentang perikatan yang timbul dari perjanjian dapat ditemukan di

28 Mariam Darus Badruzzaman, Hukum Benda Nasional, Bandung: Alumni, 1990, hlm.5. Sebagai suatu sistem, hukum terdiri dari sub-sub sistem yang satu sama lain berkaitan dalam hubungan yang seimbang, dan serasi tidak tumpang tindih,tidak berbenturan karena asas- asasnya yang terpadu. Asas-asas yang terdapat dalam hukum perdata harus senada, seirama dengan asas yang terdapat dalam Hukum Nasional, demikian juga dengan asas-asas hukum perjanjian harus senada dengan asas-asas hukum perdata

${ }^{29}$ Muhammad Arifin, Penyalahgunaan Keadaan Sebagai Faktor Pembatas Kebebasan Berkontrak, Jurnal Ilmu Hukum, Vol. 14, No. 2, September 2011, Universitas Muhammadiyah Sumatera Utara, Medan, hlm 281. 
dalam Bab III KUHPerdata mengenai perikatan-perikatan yang dilahirkan dari kontrak atau perjanjian. KUHPerdata menerjemahkan kata overeenkomst yang tertulis di dalamnya dengan kata persetujuan namun di dalam kehidupan sehari-hari untuk overeenkomst biasa disebut dengan kata perjanjian atau kontrak. Pada dasarnya istilah tersebut merupakan terjemahan dari bahasa Belanda yang berasal dari kata kerja overeenkomst yang artinya setuju atau sepakat.

Pasal 1313 KUHPerdata sendiri telah mendefinisikan perjanjian yang menyatakan bahwa "Suatu perjanjian adalah suatu perbuatan dengan mana satu orang atau lebih mengikatkan dirinya terhadap satu orang lain atau lebih. Definisi perjanjian menurut KUHPerdata tersebut kurang lengkap dan terlalu luas. ${ }^{32}$ Dikatakan kurang lengkap karena definisi tersebut hanya memberikan pengertian mengenai perjanjian sepihak saja dimana hanya satu pihak yang mempunyai kewajiban melaksanakan prestasi, sedangkan pihak lain tidak diwajibkan untuk berprestasi. Hal ini dapat dilihat dari perkataan "satu orang atau lebih mengikatkan dirinya terhadap satu orang lain atau lebih" yang seolah-olah memberikan pengertian bahwa di satu pihak hanya ada kewajiban saja dan di lain pihak hanya ada hak saja.

Perjanjian adalah hubungan hukum antara dua pihak atau lebih yang mengikatkan diri berdasarkan kata sepakat untuk menimbulkan akibat hukum. Pada perkembangannya perjanjian tidak lagi dipandang sebagai suatu perbuatan saja, tetapi merupakan suatu perbuatan hukum yang bersisi dua, artinya bahwa dalam suatu perjanjian terdapat suatu perbuatan hukum yang mempunyai dua sisi.

Sisi pertama adalah penawaran sedangkan sisi kedua adalah penerimaan. Penawaran dan penerimaan masing-masing menimbulkan akibat hukum. Berdasarkan hal tersebut perjanjian didefinisikan sebagai hubungan hukum antara dua pihak atau lebih berdasarkan kata sepakat untuk menimbulkan akibat hukum. Definisi tersebut menerangkan bahwa untuk terjadinya perjanjian harus ada kata sepakat atau consensus antara para pihak. Kata sepakat dapat diberikan secara lisan, tertulis atau bahkan dapat diberikan secara diam-diam ataupun dengan bahasa isyarat. Sehubungan dengan definisi perjanjian tersebut, lebih lanjut dikemukakan Satrio bahwa perlu kiranya diadakan perbaikan mengenai definisi tersebut, yaitu: ${ }^{30}$

a. Perbuatan harus diartikan sebagai perbuatan hukum yaitu perbuatan yang bertujuan untuk menimbulkan akibat hukum;

b. Menambahkan perkataan "atau saling mengikatkan dirinya" dalam Pasal 1313 KUHPerdata.

Berdasarkan pendapat para ahli hukum di atas, maka dapat ditarik suatu kesimpulan mengenai pengertian perjanjian yaitu suatu perbuatan hukum yang dilakukan oleh dua orang atau lebih berdasarkan kata sepakat diantara para pihak yang menimbulkan akibat hukum berupa hak dan kewajiban. Berdasarkan uraian di atas,

Abdulkadir Muhammad juga memberikan pengertian dalam versi yang sedikit berbeda, dimana perjanjian yaitu suatu persetujuan dengan mana dua orang atau lebih saling mengikatkan diri untuk melaksanakan suatu hubungan dalam hukum harta

${ }^{30}$ J. Satrio, Hukum Perikatan, Perikatan yang Lahir dari Perjanjian, Buku Kesatu, PT. Citra Aditya Bakti, 1995, Bandung, hlm. 25 
kekayaan. ${ }^{31}$ Rumusan ini lebih jauh menegaskan bahwa perjanjian mengandung unsur adanya prestasi yang harus dilakukan dan tujuan yang hendak dicapai oleh para pihak terbatas pada lapangan harta kekayaan.

Wirjono Prodjodikoro mengatakan bahwa perjanjian adalah suatu perbuatan hukum mengenai harta benda kekayaan antara dua pihak, dalam mana satu pihak berjanji atau dianggap tidak berjanji untuk melakukan suatu hal atau tidak melakukan suatu hal, sedangkan pihak yang lain berhak untuk menuntut pelaksanaan janji tersebut. $^{32}$

Dengan lahirnya perjanjian maka akan menimbulkan suatu hubungan dua orang yang dinamakan perikatan. Istilah perikatan digunakan sebagai terjemahan dari verbintenis. M. Yahya Harahap menterjemahkan verbintenis sebagai perjanjian, yang dimaksud perjanjian oleh M. Yahya Harahap adalah perikatan (verbintenis). Beliau berpendapat bahwa perjanjian mengandung suatu pengertian yang memberikan sesuatu hak pada suatu pihak untuk memperoleh prestasi dan sekaligus mewajibkan pada pihak lain untuk menunaikan prestasi. ${ }^{33}$

Mariam Darus Badrulzaman mengklasifikasikan standard contract tersebut ke dalam 2 (dua) kelompok. Pertama, perjanjian standar umum yaitu perjanjian yang bentuk dan isinya telah dipersiapkan terlebih dahulu oleh kreditor kemudian disodorkan pada debitor. Kedua, perjanjian standar khusus yaitu perjanjian ini ditetapkan oleh pemerintah secara sepihak dan diberlakukan bagi para pihak.

Konsekuensi hukum dari tidak terpenuhinya salah satu atau lebih dari syaratsyarat sahnya perjanjian tersebut bervariasi mengikuti syarat mana yang dilanggar. Konsekuensi hukum tersebut adalah sebagai berikut: (1) Batal demi hukum (netig, null and void), misalnya dalam hal dilanggarnya syarat objektif dalam Pasal 1320 KUHPerdata; (2) Dapat dibatalkan(vernieetigbaar, voidable), misalnya dalam hal tidak terpenuhinya syarat subjektif dalam Pasal 1320 KUHPerdata.

\section{PENUTUP}

Standart yang dapat dipakai untuk menentukan suatu perjanjian telah memenuhi asas iktikad baik adalah dilihat dari 2 (dua) aspek, yaitu aspek subjektif dan objektif. Aspek subjektif dimana para pihak secara terbuka memberikan informasi yang sesungguhnya tentang siapa dirinya dengan memberikan bukti berupa dokumen tentang dirinya (misalnya dokumen anggaran dasar jika Pihak dalam perjanjian adalah badan hukum PT). Aspek objektif, yaitu pada saat pelaksanaan perjanjian harus sesuai dengan kepatutan atau keadilan. Kepatutan dalam hal ini dilihat dari pelaksanaan tersebut sesuai dengan isi perjanjian yang ada. Sedangkan keadilan dapat dilihat dari apakah pelaksanaan perjanjian merugikan salah satu pihak atau tidak sesuai dengan isi perjanjian. Apabila merugikan salah satu pihak, maka pelaksanaan tersebut tidak adil (diluar dari isi perjanjian). Iktikad terbagi kepada dua hal yaitu, Iktikad baik pada waktu mulai berlakunya suatu hubungan, dalam konteks ini hukum memberikan

31 Muhammad Abdulkadir, Hukum Perikatan, PT Citra Aditya Bakti, 1992, Bandung, hlm. 78

${ }^{32}$ Wirjono Prodjodikoro, Hukum Perdata tentang Persetujuan Tertentu, Sumur, 1981, Bandung, hlm. 11.

${ }^{33}$ M. Yahya Harahap, Segi-Segi Hukum Perjanjian, Alumni, 1986, Bandung, hlm. 20. 
p-ISSN : 2541-2345, e-ISSN : 2580-8842

perlindungan bagi pihak, Iktikad baik dalam pelaksanaan hak-hak dan kewajibankewajiban yang termaktub dalam hubungan hukum itu yang beriktikad baik hukum. Berdasarkan rumusan pasal 533 KUHPerdata dinyatakan bahwa pada dasarnya setiap orang yang memegang kedudukan berkuasa baik itu penjual maupun pembeli harus senantiasa dianggap beriktikad baik selama tidak dapat terbukti sebaliknya. Adanya iktikad baik tersebut maka para pihak menyadari kewajibannya yang timbul dari adanya perjanjian jual beli. Pasal 531 KUHPerdata menyatakan bahwa seseorang itu dianggap memiliki iktikad baik apabila orang itu memperoleh suatu benda dengan cara memperoleh hak milik tanpa mengetahui adanya cacad yang terkandung dalam benda tersebut. Sebaliknya suatu keadaan yang dikatakan sebagai iktikad buruk apabila orang tersebut mengetahui bahwa benda tersebut adalah bukan miliknya. Hal ini diatur dalam pasal 532 KUHPerdata

\section{DAFTAR PUSTAKA}

\section{BUKU}

Agus Yudha Hernoko, 2008, Hukum Perjanjian: Asas Proporsionalitas dalam Kontrak Komersial, LaksBang Mediatama, Yogyakarta.

Djaja S. Meliala, 1987, Masalah Iktikad Baik dalam KUHPerdata, Binacipta, Bandung .

Henry P. Panggabean, 1999, Penyalahgunaan Keadaan, (Misbruik van Omstandigheden) sebagai Alasan (Baru) untuk Pembatalan Perjanjian (Berbagai Perkembangan Hukum di Belanda), Liberty, Yogyakarta.

J. Satrio, 1995, Hukum Perikatan, Perikatan yang Lahir dari Perjanjian, Buku Kesatu, Bandung: PT. Citra Aditya Bakti.

L.J. van Apeldoorn, 1980, Pengantar Ilmu Hukum, Pradnya Paramita, Jakarta.

Muhammad Abdulkadir, 1992, Hukum Perikatan, (Bandung: Citra Aditya Bakti.

Muhammad Arifin, 2011, Penyalahgunaan Keadaan Sebagai Faktor Pembatas Kebebasan Berkontrak, Jurnal Ilmu Hukum, Vol. 14, No. 2, September.

Muhammad Syaifuddin, 2012, Hukum Kontrak, Bandung: Mandar Maju.

Munir Fuady, 2001, Hukum Kontrak (Dari Sudut Pandang Hukum Bisnis), Bandung: PT. Citra Aditya.

Marthainis Badul Hay, 1984, Hukum Perdata Material (jilid II), Bandung: Pradnya Paramita.

M. Yahya Harahap, 1986, Segi-Segi Hukum Perjanjian, (Bandung: Alumni.

Soerjono Soekamto, 2006, Pengantar Penelitian Hukum Jakarta: UI-Press.

Subekti, 1992, Aspek-Aspek Hukum Perikatan Nasional, Bandung: PT. Citra Aditya Bakti, 
p-ISSN : 2541-2345, e-ISSN : 2580-8842

, 1983, Hukum Perjanjian, Jakarta: Citra Aditya Bakti, hlm 25

Sutrisno Hadi, 1969, Metodologi Research, Jilid I (Yogyakarta: Yayasan Penerbit Fakultas Psikologi UGM.

R.Dworkin (buku 1) , 1977, Taking Richts Seriously, Harvard University Press, Cambrigde, Massachcussetts .

(buku 2) , 1991, Low's Empire, Fontana Press, Herper Collins Publishers, London.

Richard Eddy, 2010, Aspek Legal Properti: Teori, Contoh dan Aplikasi, Yogyakarta: CV. Andi Offset.

Ridwan Khairandy, 2013, Hukum Kontrak Indonesia, Yogyakarta: UII Press.

, 2011, Landasan Filosofis Kekuatan Mengikatnya Kontrak, Jurnal Hukum No. Edisi Khusus Vol. 18 Oktober

, 2008, Iktikad Baik dalam Pelaksanaan Kontrak: Super Eminent

Principle yang Memerlukan Pengertian dan Tolok Ukur Objektif, Jurnal Hukum "Ius Quia Iustum” No. 3 Vol. 14 Juli.

Ricardo Simanjuntak, 2011, Teknik Perancangan Kontrak Bisnis, Kontan Publishing: Jakarta.

Wirjono Prodjodikoro, 1981, Hukum Perdata tentang Persetujuan Tertentu, Bandung: Sumur.

Zahry Vandawati Chumaidah, 2014, Menciptakan Iktikad Baik Yang Berkeadilan Dalam Kontrak Asuransi Jiwa, Yuridika : Volume 29 No 2, Mei-Agustus

\section{JURNAL}

Antari Innaka, 2012, Penerapan Asas Iktikad Baik Tahap Prakontraktual Pada Perjanjian Jual Beli Perumahan, MIMBAR HUKUM Volume 24, Nomor 3, Oktober.

Dewi Tuti Muryati, 2011, Pengaturan Dan Mekanisme Penyelesaian Sengketa Nonlitigasi Di Bidang Perdagangan, Journal Dinamika Sosbud Vol. 13 Nomor 1 Juni

Ery Agus Priyono, 2017, Peranan Asas Iktikad Baik Dalam Kontrak Baku (Upaya Menjaga Keseimbangan Bagi Para Pihak), Diponegoro Private Law Review Vol. 1 No. 1 November.

Gary Hadi, 2017, Penerapan Asas Iktikad Baik Dalam Perjanjian Sewa-Menyewa (Studi Terhadap Perjanjian Sewa Menyewa Oulet Di Hermes Building Medan ). USU Law Journal, Vol.5.No.2

Harisa, Novran Harisa, 2018, Asas Itikat Baik dalam Perjanjian Arbitrasi sebagai Metode Penyelesaian Sengketa, AKTUALITA, Vol.1 No.1 (Juni) .

K.M. Sharma, 1999, "From Sanctity to Fairness: An Uneasy Transition in The Law of Contract?",New York Law School Journal of International law \& Comparative Law, Vol. 18. 